$1996-6$

\title{
Increasing Husbands' Involvement in Domestic Labor: Issues for Therapists
}

Kipling S. Rasmussen

Alan J. Hawkins

Brigham Young University - Provo, hawkinsa@byu.edu

Kenneth P. Schwab

Follow this and additional works at: https://scholarsarchive.byu.edu/facpub

Part of the Other Social and Behavioral Sciences Commons

\section{Original Publication Citation}

Rasmussen, K., Hawkins, A. J., \& Schwab, K. (1996). Increasing fathers' involvement in domestic labor: Issues for therapists. Contemporary Journal of Family Therapy, 18, 209-222.

\section{BYU ScholarsArchive Citation}

Rasmussen, Kipling S.; Hawkins, Alan J.; and Schwab, Kenneth P., "Increasing Husbands' Involvement in Domestic Labor: Issues for Therapists" (1996). Faculty Publications. 4210.

https://scholarsarchive.byu.edu/facpub/4210

This Peer-Reviewed Article is brought to you for free and open access by BYU ScholarsArchive. It has been accepted for inclusion in Faculty Publications by an authorized administrator of BYU ScholarsArchive. For more information, please contact ellen_amatangelo@byu.edu. 


\title{
INCREASING HUSBANDS' INVOLVEMENT IN DOMESTIC LABOR: ISSUES FOR THERAPISTS
}

\author{
Kipling S. Rasmussen \\ Alan J. Hawkins \\ Kenneth P. Schwab
}

\begin{abstract}
As a result of the dramatic increase in women's participation in the work force, more relationship therapists are seeing couples who are dissatisfied with how domestic labor is divided in their homes. Although, this issue may seem therapeutically straightforward, there are many aspects which make its renegotiation surprisingly problematic and complex. This article is an effort to delineate some of these issues such as engaging men in therapy, exploring emotional issues connected with housework, and the mechanism of gatekeeping. Also included is a therapeutic framework for addressing client concerns about domestic responsibilities.
\end{abstract}

KEY WORDS: family therapy; domestic labor; husband involvement; dual-income couples.

The past two decades have witnessed widespread changes in familial roles, evidenced most prominently, perhaps, by the substantial increase in the percentage of married mothers in the work force. Despite this, research shows that wives are still performing the great bulk of domestic labor (Demo \& Acock, 1993; Hardesty \& Bokemeier, 1989; Pleck, 1985; Rexroat \& Shehan, 1987; Robinson, 1988). This

Kipling S. Rasmussen, $\mathrm{PhD}$, is Therapist, Whipple Heights Adolescent Day Treatment Center, 2116 Campus Drive, S.E. Rochester, MN 55904. Alan J. Hawkins, PhD, is an assistant professor of family sciences, 1000 SWKT, Brigham Young University, Provo, UT 84602. Kenneth P. Schwab, PhD, is Therapist for Children at Risk, Davis County Mental Health and Alcohol and Drug Services, P.O. Box 689, Farmington, UT 84025. Reprint requests should be sent to the first author. 
tendency for wives to return home from full-time jobs only to begin hours of household labor and child care has been called the second shift (Hochschild, 1989).

Carter and McGoldrick (1989) have indicated that the allocation of child care and housework is a central conflict for transition-to-parenthood couples. They maintain, moreover, that it is impossible to reach successful outcomes with these couples without dealing with core issues of gender role functioning. A growing body of research suggests that it may indeed be of critical importance to satisfaction and stability in marriage. Hochschild (1989), for example, found that the happiest couples in her longitudinal study were those in which the husbands participated equitably in daily housework and child care. In addition, several studies indicate that the psychological health of both mothers and husbands was higher if both spouses shared in housework (Hochshild, 1989; Hoffman, 1989, Pleck, 1985). Huber and Spitze (1983) also noted that the less husbands participated in domestic work, the more likely their wives were to think of or consider divorce.

Gottman (1991) reported that men who participated in domestic work were "less overwhelmed by their wives' emotions, less avoidant of conflict and had lower heart rates during marital conflict than men who did no housework" (p. 6). Similarly, Cowan and Cowan (1992), through longitudinal research, found marked differences in marital quality and stability between couples experiencing the transition to parenthood who had participated in a preventive group therapy intervention and couples who did not participate, and concluded that the allocation of domestic labor may constitute a significant protective factor against marital dissolution in the early parenting years.

Despite the attention given the unequal division of domestic labor in popular (Rubin, 1983) and family sciences literature, there seems comparatively little focus afforded within the family therapy literature (Carter, 1992). Within family science writing, attention seems long on discussion and short on ideas for intervention (Hawkins \& Roberts, 1992). This is particularly surprising in light of the attention given in the media to husband involvement during the past few years (Blankenhorn, 1995). Authors of one recent review of divorce intervention literature found no studies that included strategies aimed at increasing husbands' involvement in child care (Lee, Picard, \& Blain, 1994). The lack of practical ideas as to how to approach this problem is even more surprising given that certain aspects of this seemingly straightforward phenomenon often prove un- 
KIPLING S. RASMUSSEN, ALAN J. HAWKINS, AND KENNETH P. SCHWAB

expectedly complex in therapeutic contexts. Indeed. we have found that, as Braverman (1991) has suggested, "getting" men to participate more in housework and parenting duties is "troublesome, problematic, and complex" (p. 25).

\section{CLINICAL ISSUES AFFECTING RENEGOTIATION OF DOMESTIC LABOR}

\section{Gender Identity and Housework}

While the renegotiation of the division of domestic labor is a task important enough in itself, we have found, from a therapeutic standpoint, that it can also serve as a doorway to issues at the very foundation of many gender differences in marital relationships. This problem is compounded by the fact that, at least in this area, the change in attitude and behavior is usually required more of men than women. This may become problematic in that we, along with others (Dienhart \& Avis, 1994), have found men to be, in general, more difficult to engage in therapy, especially in sessions in which their behavior is central to discussion.

This gender identity problem suffuses all discussion of labor distribution patterns because it reveals, in detail, the personal meanings about gender and gender roles which both husbands and wives hold for a wide variety of life issues (Broderick, 1979; Greenberg \& Johnson, 1988; Rubin, 1983). Obviously, some men find that when it comes to actual practice, they remain uncomfortable even still with the idea of housework and child care. While this seems archaic to most clinicians (Braverman, 1991; Carter, 1992), many men, nevertheless, find it difficult to envision themselves in, let alone assume a domestic role. We have found that this discomfort almost invariably signals underlying beliefs involving the idea that performing domestic tasks is somehow unmasculine. Where this attitude is present, rather than outright confrontation of this questionable logic, we have found it more useful to explore the personal meanings such an attitude usually represents (Erickson, 1993; Broderick, 1979).

Like others (Dienhart \& Avis, 1994), we believe that certain therapeutic vehicles are more suited to the male experience than others and that these should be learned in order to maximize effectiveness with male clients. We have noticed that if emotional expression which all too often has been considered feminine by our culture (e.g., weep- 


\section{CONTEMPORARY FAMILY THERAPY}

ing) arises in session, it can be forcefully repressed by many men. We believe that because men, for a variety of reasons, have been socialized to limit their emotional expression, and because men, therefore, have less permission for and experience of intense affect, they may fear these emotions to some extent. Using the approaches outlined below, however, we have found that these emotions do arise, and can be dealt with therapeutically.

To access this portion of client experience, we have found two approaches, both of which involve history-taking, to be helpful. One of these is the family-of-origin approach derived from Bowen theory (Kerr \& Bowen, 1988). Interestingly, exploratory research has suggested that family-of-origin approaches such as this are widely used by clinicians working with men (Dienhart \& Avis, 1994). One reason for its popularity is certainly because Bowen therapy may be framed readily as "research" of the client's family of origin rather than as a more straightforward challenge to the client's justification for lack of participation. Men are usually less defensive when their family of origin is the focus rather than their own behavior. Used in this way, Bowen theory is particularly helpful in accessing private emotional attitudes and beliefs pertaining to gender and gender roles which have been transmitted and internalized generation upon generation, often without conscious awareness (Kerr \& Bowen, 1988). As these issues are probed using genograms and family research (Kerr \& Bowen, 1988) and both partners begin to understand themselves (and to feel understood), we have found that resistance tends to fade. Also, as realizations are made as to just how restrictive these attitudes can be, many men actually begin to feel liberated not only to participate more around the home, but also in more emotionally comprehensive ways as well (Dienhart \& Avis, 1994).

Another model useful for these matters is the Structured Initial Interview (SII) (Hiebert, Gillespie, \& Stahmann, 1993), a method enabling clinicians to graph the course of the husband-wife relationship from first glance, through courtship to the present session. Questions asked during the SII can be tailored to emphasize any given problem. For the issue in question, therapists trace the evolution and trajectory of the couple's household participation patterns, thus allowing them a broad developmental overview. Questions asked typically include, "When you first started spending time at the house of the other, what struck you about how they did things?" or "When you returned from your honeymoon to your home, how did you arrange who would perform what tasks? Did you just fall into it? Did one 
KIPLING S. RASMUSSEN, ALAN J. HAWKINS, AND KENNETH P. SCHWAB

partner do the tasks without asking for help or was the help not given, and then never asked for again?" The information obtained from these questions is then noted graphically on a wallboard as it is related. In this way, the SII allows clients to view how the original division of labor was negotiated and how it progressed or deteriorated over time.

The approaches described enable wives to at least understand the context of the problem, if not accept the probable emotional reasoning underpinning their husbands' reluctance to engage in domestic labor. They thus tend to portray men as individuals who have purposes that are rational to them, though they do not excuse them from responding to their partners' requests.

\section{Dyadic Homeostasis and Gatekeeping}

Domestic task performance can have great emotional significance to women as well, though for possibly different reasons. One of the most curious aspects of increasing involvement in the domestic sphere is the phenomenon of gatekeeping (Haas, 1992; Hawkins \& Roberts, 1992). Gatekeeping is the tendency for many wives to resist, or manage, their husbands' efforts to increase participation in the home-viewing it, perhaps, as an invasion of or encroachment into their domain. A substantial body of research (Cowan \& Cowan, 1987; Haas, 1992; Hochshild, 1989; Pleck, 1985) indicates that wives-even those who are working full-time-are sometimes reluctant to relinquish their control over the home front.

One client family presented with concerns about two adolescent sons, but it soon became apparent that there were serious marital problems to be addressed as well. The husband worked two jobs in addition to fulfilling a time consuming church position and felt he was fulfilling his fatherly duty by providing financially for his family. His wife, however, was left with a part-time job, church responsibilities, child care, and all the housework duties. Moreover, the children, particularly the two adolescents, appeared to be yearning for more attention and guidance from their father, and were forcing this attention through misbehavior. After several sessions, the father agreed to eliminate some of his duties outside the home and participate more fully in family and domestic life. Yet, as he began to assume some of the household and child care tasks, his wife began to complain that her husband was not doing things "right," that he messed up "her" kitchen, and that it was easier to do it all herself. After 
the husband expressed his concern about this tendency to protect her territory in the therapy session, she began to relinquish some of her "control." Thereafter, the husband did become more involved with the family, while the wife found that she enjoyed the extra time, and therapeutic progress continued.

Some researchers have speculated that gatekeeping may serve to protect women's' sense of self, since the kinds of employment outside the home most available to mothers do not generally pack the same prestige punch as that of their husbands (Carter, 1992). Competence and participation on the part of men in an area formerly considered more the province of women may undermine their sense of importance, leading them, perhaps, to the conclusion that they are readily replaceable. Relinquishing control over the home still seems to have considerable implications for the gender identity and self-esteem of many women, even those with full-time jobs outside the home.

When gatekeeping appears, we again explore the possible emotional meanings that control over the domestic arena may have for women. A wife, for example, may complain of receiving little participation from her husband but find, upon getting more participation, that she is losing control over possibly one of the few realms in her life which she can order as she will. Perhaps she may find, in the beginning at least, that she would rather have this hegemony over the home than the increased time for other things that her husband's participation in housework would give her. However, it has been our experience that as men begin to participate more around the house, most women do find that life is better when performing only a shift and a half.

\section{Managerial Responsibility}

One often overlooked aspect of domestic labor concerns is managerial responsibility, that is, the duty to plan the task and see that it gets done properly. If, for example, a husband agrees to prepare the evening meal every other day but prepares a meal planned by his wife, he is not taking managerial responsibility for the task. Similarly, if he neglects to ensure that the ingredients necessary to the preparation of these meals are included on the previous week's shopping list, he is failing to take this managerial outlook. Again, research (Hawkins, Roberts, Christiansen, \& Marshall, 1994) has indicated that men are less likely to assume managerial responsibility for domestic tasks even when they are performing the tasks. Moreover, we 
have found that most couples do not view this issue as distinct from actually performing the task. Thus, if the concept of managerial responsibility is not explicitly delineated in sessions together with the negotiation of task performance, it is unlikely that a novice task participant will be aware of the larger, more encompassing responsibility connected with the job.

One father was glad to take the baby to the doctor for immunizations and checkups, but this occurred only when the mother, who was keeping track of the visits, remembered the timing of the checkups and made the appointments. Although the participation of the father was laudable, this system required the mother to track immunizations still needed by the baby. With further participation, the husband, by bringing the baby to the physician's office and hearing the doctor's instructions concerning future checkups, gained an understanding of the wider managerial responsibility involved in infant care and the increased planning required for their accomplishment.

\section{Standards Issues}

Within a short time after marriage, or even before marriage in many cases, relationship partners learn that they may have widely varying ideas as to how and when household tasks should be done. Just how gray must the bathroom become before one spouse, in disgust (and resentment), cleans it? By the other spouse's criteria, perhaps, the bathroom was not particularly dirty. This disagreement is one of standards and is an issue which must be addressed if progress is to be made. How is a task to be done? Should the carpet be vacuumed from front to back, moving backwards so that no footprints are left on the carpet? Must chairs be moved and the carpet underneath vacuumed? Tasks considered irrelevant or trivial by one partner may be terribly important to the other. This again is particularly critical where child-care tasks are concerned. How often must the children be bathed and what life activities must each partner sacrifice in order to provide an optimal level of general child-care?

During preparation of a questionnaire for a proposed longitudinal study, one couple complained of the ambiguity of a proposed scale item which required respondents to rate the level of change in task participation they desired from their spouse. Surprisingly, one husband reported that he wanted much less participation from his wife on one aspect of domestic labor. When questioned, the subject indicated that he did not want her to do less, but that he did not think the 
task needed to be done as often as the wife performed it. As trivial as standards disagreements may seem to onlookers, we have found that even seemingly small disagreements may become matters of clinical importance if they are tied to emotionally significant issues. Also, these are frequently linked to family of origin experience. Having a clean house, for example, may have special importance if the wife's mother was fastidious and if being clean meant closeness to (or possibly resentment towards) her as they cleaned together in her youth. Indeed, one client husband linked cleanliness with a general feeling of well-being extending far beyond the obvious benefits of having a clean environment. To him, cleanliness was indeed next to godliness, and to achieve this he was willing to spend considerably more time performing domestic chores than his wife, although he did want more participation from her. Personal meanings concerning differing standards such as these are frequently signaled during therapy sessions if a spouse exhibits a degree of hesitancy which, at situational facevalue, appears unwarranted when he or she is asked by the other spouse to make some "reasonable" change. Because these matters are personal and idiosyncratic, when spouses have agreed to increase their participation in some task, those who previously performed the task must make explicit what their ideas of tasks well-done are.

One helpful intervention approach is having the spouse who was formerly responsible for the job guide the newly responsible spouse through it once or twice to make sure the new participator understands what accomplishing the task actually entails. Alternatively, the spouse who is new to the task may perform it using his or her method for two or three weeks without interference. In this way, a new perspective of the task may yield new and better methods for both spouses as well as fitting a particular performance style better.

\section{Differing Standards versus Minimum Acceptable Standard of Performance}

A distinction must be made between ordinary domestic tasks and those tasks which require being done correctly, or at a certain minimum standard of performance if serious consequences are to be avoided. This category of tasks involves more than simple disagreement over whether the dishes are washed immediately after dinner or in two hours. Some tasks are so important-aside from the emotional importance placed on them by the participants-that doing them implies a certain required level of performance. Many of these tasks are 
KIPLING S. RASMUSSEN, ALAN J. HAWKINS, AND KENNETH P. SCHWAB

related to care of children. Other tasks in this category involve those things which, if done improperly, pose hazards to the health and safety of family members, for example, preparing certain foods correctly and maintaining good sanitation.

We believe therapists have some obligation to ensure that clients consider which domestic tasks require this minimum performance level and are thus, at least as far as how these tasks are performed, nonnegotiable. The tendency to let important tasks slide seems to manifest itself especially when novice caretakers are left in charge of tending children. One woman, for example, complained that her children were so accustomed to appealing to her when they were hungry at lunchtime that when she went shopping and left them in the care of their father, they neglected to tell him they were hungry. When she walked through the door several hours later, the children, suddenly alerted to their famished state, would clamor for her to fix them lunch. When asked about neglecting to feed the children, the father said, "I didn't know they were hungry."

\section{A TWO-DIMENSIONAL MODEL OF DOMESTIC TASK}

\section{Emotionality and Criticality}

For the purpose of practical negotiation of tasks such as these, we have found it useful to utilize a two dimensional model (which we draw on a wallboard) for domestic task classification (see Table 1). On the horizontal axis lies the Criticality continuum, consisting of three categories of housework on which may be placed any domestic task to be discussed. This axis allows graphical display of the "objective" importance of a given task, or, how critical it is that a task be completed correctly. For ease of use, it is divided into three sections. First (from left to right), there are the noncritical tasks or those tasks which carry no objectively correct method of accomplishment. This may include such things as whether the carpet is vacuumed once or twice a week or whether the bed is made every day. These are clearly "standards" issues unless one spouse attaches some special emotional meaning to them. The second category consists of tasks which need to be done correctly but which are not critical, for example, ensuring that children get to bed at a time which preserves a semblance of bedtime routine. The third category is comprised of those tasks which require a minimum standard of performance in order to avoid possi- 
CONTEMPORARY FAMILY THERAPY

TABLE 1

Task Performance Continuum Criticality

\begin{tabular}{|c|c|c|c|}
\hline Emotionality & $\begin{array}{l}\text { Noncritical } \\
\text { Tasks }\end{array}$ & $\begin{array}{l}\text { Midrange } \\
\text { Tasks }\end{array}$ & $\begin{array}{l}\text { Critical } \\
\text { Tasks }\end{array}$ \\
\hline High & $\begin{array}{l}\text { Making bed } \\
\text { every day. Wak- } \\
\text { ing up to clean } \\
\text { kitchen. }\end{array}$ & $\begin{array}{l}\text { Putting kids to } \\
\text { bed at same } \\
\text { time each night. }\end{array}$ & $\begin{array}{l}\text { Changing dia- } \\
\text { pers. Feeding } \\
\text { children. }\end{array}$ \\
\hline Medium & $\begin{array}{l}\text { Vacuuming } \\
\text { twice a week. }\end{array}$ & $\begin{array}{l}\text { Washing the lig- } \\
\text { ht clothes } \\
\text { separate from } \\
\text { the darks. }\end{array}$ & $\begin{array}{l}\text { Monitoring kids' } \\
\text { nutrition. }\end{array}$ \\
\hline Low & \multicolumn{3}{|c|}{$\begin{array}{l}\text { Note: This cell is often empty or is used for partner } \\
\text { comparison, i.e., wife may say, "I consider such and } \\
\text { such task of little importance, and so I would put it in } \\
\text { the low emotionality cell." }\end{array}$} \\
\hline
\end{tabular}

ble harm to an individual, changing diapers promptly, for example. This category can be considered much less subjective than all others on the graph.

On the vertical axis is a continuum of Emotionality, or the personal, idiosyncratic importance placed on a given task by the client couple. This axis is generally the most important one for purposes of renegotiation of domestic labor, and may contain virtually any task, no matter how insignificant it may seem to a partner or therapistfrom where to squeeze the toothpaste tube to frequency of closet cleaning. Obviously, although tasks high on the criticality scale will usually be high on the emotionality scale as well, the reverse is not necessarily true: tasks of great emotional significance will not necessarily be "objectively" critical.

In our experience, the most difficult area in the model is the noncritical/high emotionality cell. Though catastrophe will never result if a bed, for example, is not made, a spouse, for reasons of his or her own, may feel strongly about the importance of doing so. If there is no harm done to the partner in fulfilling the task, we believe this subjective importance should be respected. Obviously, it is crucial that a spouse or therapist refrain from dismissing a given task as unimpor- 
KIPLING S. RASMUSSEN, ALAN J. HAWKINS, AND KENNETH P. SCHWAB

tant without investigating the personal meaning it may have for the individual. As in many other instances, therapists must decide when this emotional importance is excessive or seems unwarranted and raise this possibility, or, on the other hand, whether attempts should be made to help the other spouse respect or respond to the personal meaning expressed.

\section{Equity and Equality}

In negotiating participation in household work and child care, a distinction might profitably be made between the concepts of equity and equality. Equality implies that the household tasks are divided into two like portions and that both husband and wife take one of these "halves" upon themselves in a quantitatively "equal" manner. This implies a more objectively fair division of labor, one example being a couple separating all household tasks onto two lists, with each spouse doing their respective tasks for a specified period, perhaps for one week, and then switching lists for an equal period of time as in the familiar role-reversal exercises. Equity implies that although household tasks may appear to be divided unequally to an outsider, the couple-both husband and wife-may be satisfied with the arrangement and may not require further renegotiation for the sake of marital satisfaction.

The therapist overseeing the negotiation for redistribution of household labor must exercise care to let couples dictate what they believe is equitable. Again, while the given couple's division of labor may not seem equitable to therapists or clinicians, if it works for the couple, we believe that we must restrain ourselves from intervention beyond the statement, perhaps, that things do not seem fair to an "objective" outsider (Becvar \& Becvar, 1988). In doing this, we, as clinicians and as ostensible experts, tread the uncertain, often narrow ground between letting "injustice" go without being rectified (Carter, 1992) and introducing more doubt than we ameliorate due to our personal values concerning the correct way for relationships to be (Becvar \& Becvar, 1988). We believe that this is the very class of issue which most readily tests therapists' skills and where the art of therapy is truly applied (Dienhart \& Avis, 1994).

Most therapists, particularly feminist clinicians, but including, we suspect, scholars from other therapeutic orientations, would place value on the theoretical concepts of egalitarianism and equality in relationships (Carter, 1992). In daily practice, however, the opera- 
tionalization of these concepts is considerably more problematic and nebulous (Thompson, 1991). A couple may include many factors in their agreement. They may, for example, include not just number of hours worked per week, but income level too. If one spouse earns more than another and they, that is, both spouses feel this is a legitimate factor to consider, we believe that therapists must accept this definition of equity.

On the other hand, although we have a certain obligation to remain neutral, we also acknowledge that neutrality is, in daily practice, a virtual impossibility for thinking, feeling creatures. We believe we must exercise extreme caution but that we should be invested in "fairness." Yet we also maintain that therapists have the obligation to make our biases explicit to clients. Again, matters such as this seem to be the very crucible of the therapeutic process.

\section{Rewards of Participation}

Research indicates that, since men are usually doing less work in the household (Pleck, 1985; Rexroat \& Shehan, 1987; Seltzer, 1991), negotiation for change will usually center on increasing male participation in the home. We believe that focusing on the potential rewards for increased participation rather than on what they are doing wrong can be more conducive to eliciting change from clients. In this way, we have attempted to steer away from what has been called the deficit model of change (Doherty, 1991). With regard to the potential rewards for increased involvement, therapists may cite considerable empirical and anecdotal evidence of the satisfaction, and marital stability, experienced by men as they became more involved in caring for and nurturing their families (Beer, 1983; Greene, 1984; Levine, 1976; Lewis, 1986; Snarey, 1993; Yarrow, 1985). And, while housework may not hold the same rewards as child care for most adults, therapists may point out that performing daily household tasks conjointly with other family members can be reframed as a valuable opportunity for husband/fathers to converse and create a more profound sense of connectedness with both wives and children (Ahlander \& Bahr, 1995; Hawkins et al., 1994; Lee, 1959). Surprisingly, chatting about the day's and life's events while engaged in housework and domestic tasks may be one of the undiscovered windows of togetherness and emotional connection for many couples and families (Hawkins et al., 1994). Indeed, for many extremely busy couples, the bulk of whose time is taken up by that which is day-to-day essential, doing necessary domestic tasks together may be one of the only opportunities for 
KIPLING S. RASMUSSEN, ALAN J. HAWKINS, AND KENNETH P. SCHWAB

communication throughout the day. Moreover, the side-to-side communication style of talking while engaging in these tasks is often more to the liking of men (Levant, 1992).

Cowan and Cowan (1992) point out that the worlds of husbands and wives often diverge when they become parents and are confronted with the great variety of child care tasks attendant to the transition to parenthood. We believe, as mentioned, that sharing housework and child care duties may help to merge these separate worlds again. There can be, of course, much that is gratifying and relationship enhancing in caring for children (Snarey, 1993; Hawkins, Christiansen, Sargent, \& Hill, 1993), as well as in accomplishing household tasks together with other family members.

\section{Discouragement Inoculation}

This notwithstanding, studies have shown that when men begin to take more responsibility for housework and child care they may experience increased frustration initially (Cowan \& Cowan, 1992), with an attendant decrease in self-esteem (Hawkins \& Belsky, 1989). Men who begin to participate in housework and child care may feel the beginners' anxiety experienced by anyone attempting new and challenging activities and yet not recognize this as expectable beginner's frustration because they may view domestic work as relatively menial and simplistic (Hawkins et al., 1993). Newly participating husbands may need warning from the outset that they will probably experience frustration, that this is normal, and that they might experience even more negative emotions before the potential rewards are realized. Learning to notice that things need to be done in the home, then doing them, constitutes a substantial lifestyle change for some clients, a change not made without some feelings of awkwardness. An additional issue is the reaction these newly participating men may encounter from more traditional minded male (or female) peers. Unexpectedly, this negative reaction can also come from clients' own parents if they perceive their children's' increased involvement as a criticism of the way they divided domestic labor (Cowan \& Cowan, 1992).

\section{SUMMARY}

As therapists, we stand in astonishment at the power of seemingly trivial things to create monumental power struggles and subsequent relationship rifts. Although household tasks may seem unim- 


\section{CONTEMPORARY FAMILY THERAPY}

portant compared to other matters, they are the very stuff of marital and family life itself. While often they are the manifest symptoms of deeper relationship difficulties, there are other instances in which the little things are the issues, straightforward and crucial. To ignore them may be to mystify the therapeutic process unnecessarily or draw artificial boundaries between issues of process and content. To address "who-does-what" problems as well as issues of logistics and nuts and bolts does improve daily lives. If indeed, the personal is political, then the trivial may certainly be of great importance within extremely close relationships. Given the amount of research indicating the importance of fathers' participation in the home, we owe it to client couples to take these issues seriously and consider them a critical component of the therapeutic process.

\section{REFERENCES}

Ahlander, N. R., \& Bahr, K. S. (1995). Beyond drudgery, power and equity: Toward a moral discourse on household labor. Journal of Marriage and the Family, 57, 54-68.

Becvar, D. S., \& Becvar, R. J. (1988). Family therapy: A systemic integration. Boston: Allyn and Bacon.

Beer, W. R. (1983). Househusbands: Men and housework in American families. New York: Praeger.

Blankenhorn, D. (1995). Fatherless America: Confronting our most urgent social problem. New York: Basic Books.

Braverman, L. (1991). The dilemma of housework: A feminist response to Gottman, Napier, and Pittman. Journal of Marital and Family Therapy, 17, 25-28.

Broderick, C. (1979). Couples: How to confront problems and maintain loving relationships. New York: Simon \& Shuster.

Carter, B. (1992, January/February). Stonewalling feminism. The Family Therapy Networker, pp. 65-69.

Carter, B., \& McGoldrick, M. (Eds.) (1989). The changing family life cycle: A framework for family therapy (Second Edition). Boston: Allyn and Bacon.

Cowan, C. P., \& Cowan, P. A. (1992). When partners become parents: The big life change for couples. New York: Basic Books.

Cowan, C. P., \& Cowan, P. A. (1987). Men's involvement in parenthood: Identifying the antecedents and understanding the barriers. In P. W. Berman \& F. A. Pedersen (Eds.), Men's transitions into parenthood: Longitudinal studies of early family experience (pp. 145-174). Hillsdale, NJ: Erlbaum.

Demo, D. H., \& Acock, A. C. (1993). Family diversity and the division of domestic labor: How much have things really changed? Family Relations, 42, 323-331.

Dienhart, A \& Avis, J. M. (1994). Working with men in family therapy: An exploratory study. Journal of Marital and Family Therapy, 20, 397-417.

Doherty, W. J. (1991). Beyond reactivity and the deficit model of manhood: A commentary on articles by Napier, Pittman, and Gottman. Journal of Marital and Family Therapy, 17, 29-32.

Erickson, R. J. (1993). Reconceptualizing family work: The effect of emotion work on perceptions of marital quality. Journal of Marriage and the Family, 55, 888-900. 
KIPLING S. RASMUSSEN, ALAN J. HAWKINS, AND KENNETH P. SCHWAB

Gottman, J. M. (1991). Predicting the longitudinal course of marriages. Journal of Marital and Family Therapy, 17, 3-7.

Greenberg, L. S., \& Johnson, S. M. (1988). Emotionally focused therapy for couples. New York: Guilford.

Greene, B. (1984). Good morning, merry sunshine. New York: Atheneum.

Haas, L. (1992). Equal parenthood and social policy. Albany, NY: SUNY Press.

Hardesty, C., \& Bokemeier, J. (1989). Finding time and making do: Distribution of household labor in nonmetropolitan marriages. Journal of Marriage and the Family, 51, 253-267.

Hawkins, A. J., \& Belsky, J. (1989). The role of father involvement in personality change in men across the transition to parenthood. Family Relations, 38, 378-384.

Hawkins, A. J., Christiansen, S. L., Sargent, K. P., \& Hill, E. J. (1993). Rethinking fathers' involvement in child care: A developmental perspective. Journal of Family Issues, 14, 531-549.

Hawkins, A. J., Roberts, T.-A. (1992). Designing a primary intervention to help dualearner couples share housework and child-care. Family Relations, 41, 169-177.

Hawkins, A. J., Roberts, T.-A., \& Christiansen, S. L., \& Marshall, C. M. (1994). An evaluation of a program to help dual-earner couples share the second shift. Family Relations, 43, 213-220.

Hiebert, W. J., Gillespie, J. P., \& Stahmann, R. F. (1993). Dynamic assessment in couple therapy. New York: Lexington Books.

Hochschild, A. (1989). The second shift: Working parents and the revolution at home. New York: Viking.

Hoffman, L. W. (1989). Increasing fathering: Effects on the mother. In M. E. Lamb \& A. Sagi (Eds.), Fatherhood and family policy (pp. 167-190). Hillsdale, NJ: Erlbaum.

Huber, J., \& Spitze, G. H. (1987). Sex stratification: Children, housework and jobs. New York: Academic Press.

Kerr, M. E. \& Bowen, M. (1988). Family evaluation. Markham, Ontario: Penguin.

LaRossa, R. (1988). Fatherhood and social change. Family Relations, 37, 451-457.

Lee, C. M., Picard, M. \& Blain, M. D. (1994). A methodological and substantive review of intervention and outcome studies for families undergoing divorce. Journal of Family Psychology, 8, 3-15.

Lee, D. (1959). The joys of participation. In Freedom and culture (pp. 27-38). Englewood Cliffs, NJ: Prentice-Hall.

Levant, R. F. (1992). Toward the reconstruction of masculinity. Journal of Family Psychology, 5, 379-402.

Levine, J. A. (1976). Who will raise the children? New options for fathers (and mothers). Philadelphia: Lippincott.

Lewis, C. (1986). Becoming a father. England: Open University Press.

Pleck, J. H. (1985). Working wives/working husbands. Beverly Hills, CA: Sage.

Rexroat, C. \& Shehan, C. (1987). The family life cycle and spouses' time in housework. Journal of Marriage and the Family, 49, 737-750.

Robinson, J. P. (1988, December) Who's doing the housework? American Demographics, pp. 24-28, 63 .

Rubin, L. B. (1983). Intimate Strangers: Men and women together. New York: Harper \& Row.

Seltzer, J. A. (1991). Relationships between fathers and children who live apart: The father's role after separation. Journal of Marriage and the Family, 53, 79-101.

Snarey, J. (1993). How fathers care for the next generation: A four-decade study. Cambridge, MA: Harvard University Press.

Thompson, L. (1991). Family work: Women's sense of fairness. Journal of Family Issues, 12, 181-196.

Yarrow, L. (1985, September). Fathers speak out. Parents, pp. 91-94. 